\title{
Potential role of D-myo-inositol-3-phosphate synthase and 14-3-3 genes in the crosstalk between Zea mays and Rhizophagus intraradices under drought stress
}

\author{
Tao $\mathrm{Li}^{1}$ • Yuqing Sun ${ }^{1} \cdot$ Yuan Ruan ${ }^{2}$ - Lijiiao Xu ${ }^{1}$ - Yajun Hu ${ }^{1,3}$ - Zhipeng Hao ${ }^{1}$. \\ Xin Zhang ${ }^{1} \cdot$ Hong $\mathrm{Li}^{1} \cdot$ Youshan Wang ${ }^{4} \cdot$ Liguo Yang $^{5} \cdot$ Baodong Chen $^{1}$ (D)
}

Received: 17 March 2016 / Accepted: 12 July 2016 / Published online: 25 July 2016

(C) Springer-Verlag Berlin Heidelberg 2016

\begin{abstract}
Arbuscular mycorrhizal (AM) symbiosis is known to stimulate plant drought tolerance. However, the mechanisms underlying the synergistic responses of the symbiotic partners to drought stress are largely unknown. A split-root experiment was designed to investigate the molecular interactions between a host plant and an AM fungus (AMF) under drought stress. In the two-compartment cultivation system, an entire or only a half root system of a maize plant was inoculated with an AMF, Rhizophagus intraradices, in the presence of localized or systemic drought treatment. Plant physiological parameters including growth, water status, and phosphorus concentration, and the expression of drought tolerance-related genes in both roots and $R$. intraradices were recorded. Although mycorrhizal inoculation in either one or both compartments systemically decreased abscisic acid (ABA) content in the whole root system subjected to systemic or local drought stress, we observed local and/or systemic AM effects
\end{abstract}

Electronic supplementary material The online version of this article (doi:10.1007/s00572-016-0723-2) contains supplementary material, which is available to authorized users.

Baodong Chen

bdchen@rcees.ac.cn

1 State Key Laboratory of Urban and Regional Ecology, Research Center for Eco-Environmental Sciences, Chinese Academy of Sciences, Beijing 100085, China

2 Department of Botany, University of British Columbia, Vancouver V6T 1Z4, Canada

3 Institute of Subtropical Agriculture, Chinese Academy of Sciences, Changsha 410125, China

4 Institute of Plant Nutrition and Resources, Beijing Academy of Agriculture and Forestry Sciences, Beijing 100097, China

5 Beijing Agricultural Machinery Experiment Appraisal Popularization Station, Beijing 100079, China on root physiological traits and the expression of functional genes in both roots and $R$. intraradices. Interestingly, the simultaneous increase in the expression of plant genes encoding D-myo-inositol-3-phosphate synthase (IPS) and 14-3-3-like protein GF14 (14-3GF), which were responsible for ABA signal transduction, was found to be involved in the activation of 14-3-3 protein and aquaporins (GintAQPF1 and GintAQPF2) in $R$. intraradices. These findings suggest that coexpression of IPS and $14-3 G F$ is responsible for the crosstalk between maize and $R$. intraradices under drought stress, and potentially induces the synergistic actions of the symbiotic partners in enhancing plant drought tolerance.

Keywords Abscisic acid · Arbuscular mycorrhizal fungus · Drought tolerance $\cdot$ Gene regulation $\cdot$ Maize $\cdot$ Rhizophagus intraradices

\section{Introduction}

Drought stress is detrimental to plant growth and development (Denby and Gehring 2005). Nevertheless, plants have evolved mechanisms to cope with drought stress at cellular, tissue, and whole-plant levels (Bray 1997). For example, following epidermal cell differentiation and polar establishment, lateral root development occurs, which plays critical roles in plant water and nutrient absorption and leads to whole-plant physiological responses to drought stress (De Smet et al. 2006; Libault et al. 2010). It has been demonstrated that the abovementioned physiological processes are initiated and sustained by signal transduction pathways mediated by endogenous stimuli, for instance plant hormones (Fujii and Zhu 2012; Osakabe et al. 2013). Comparison of biosynthesis and catabolism of abscisic acid (ABA) in drought-tolerant and 
drought-sensitive plants revealed that drought-tolerant plants accumulated less ABA when subjected to drought stress, demonstrating differential ABA homeostasis between plant genotypes ( $\mathrm{Ji}$ et al. 2011). As a primary stress hormone, ABA helps to maintain plant water status by activating downstream stress-responsive genes (Hauser et al. 2011; Joshi-Saha et al. 2011; Fujii and Zhu 2012). Accumulating evidence indicates that ABAmediated drought tolerance is associated with the induction of both regulatory and functional gene products (Shinozaki and Yamaguchi-Shinozaki 2007). The regulatory proteins consist of protein factors regulating ABA signal transduction and expression of ABA-responsive functional genes, the proteins containing ABAresponsive element (ABRE) core sequences in their putative promoter region, and also those involved in ABA biosynthesis (Jia et al. 2006). According to the data obtained from a cDNA macroarray (Jia et al. 2006), there are two special regulatory proteins among 79 gene products up-regulated by drought stress, including Dmyo-inositol-3-phosphate synthase (IPS) and 14-3-3-like protein GF14 (14-3GF). IPS plays the most important role in de novo synthesis of myo-inositol and is the only gene containing ABRE core sequences in its promoter. 14-3GF exhibits a unique positive response to drought stress among members of the 14-3-3 protein family. Consequently, the activated functional proteins like water channels and detoxification enzymes are considered to play crucial roles in adjusting cellular osmotic potential and protecting cells from active oxygen under stressful conditions (Seki et al. 2002; Camp et al. 2003).

Arbuscular mycorrhizal (AM) symbiosis, an association between AM fungi (AMF) and roots of higher plants, can be found in most terrestrial ecosystems. It has been well established that AMF not only supply host plants with water and nutrients (Augé 2001; Li et al. 2013, 2014), but also improve their photosynthesis (Ruíz-Sánchez et al. 2011) and modulate metabolic processes like ABA synthesis (Herrera-Medina et al. 2007). According to GeneChip data comparing the transcriptional profiles of mycorrhizal and non-mycorrhizal roots (García Garrido et al. 2010), five genes encoding enzymes relevant to ABA biosynthesis were up-regulated in mycorrhizal roots. Among the enzymes, 1-deoxy-D-xylulose 5-phosphate synthase 2 (DXS) and 1-deoxy-D-xylolose 5-phosphate reductoisomerase (DXR) are involved in isoprenoid metabolism, while phytoene desaturase (PDS), zeta-carotene desaturase (ZDS), and aldehyde oxidase (AO) are involved in carotenoid metabolism. AMF also were found to protect plants against drought stress by regulating plant endogenous ABA concentration (Estrada-Luna and Davies 2003). Hormonal signals are responsible for direct or indirect communication between roots and shoots (Jeschke and Hartung 2000). Root-derived ABA can be translocated to shoots by long-distance xylem transport and a portion of xylem-borne ABA will be recycled back to the roots via phloem (Peuke et al. 1994, 2002). Shoot but not root growth is inhibited by an increase in shoot ABA concentration (Munns and Sharp 1993), suggesting the potential role of ABA as a local growth regulator (Munns and Sharp 1993; Jeschke and Hartung 2000). However, it remains unknown how AMF mediate ABA distribution under drought stress.

Changes in plant ABA concentration caused by AMF have been postulated to induce the expression of many stressrelated genes including aquaporin genes encoding membrane intrinsic proteins that facilitate transport of certain small molecules in addition to water across biological membranes (Porcel et al. 2006a), p5cs genes encoding a rate-limiting enzyme in proline biosynthesis (Porcel et al. 2004), and nced genes coding for a key enzyme in ABA biosynthesis (Aroca et al. 2008). Although Aroca et al. (2008) demonstrated a positive correlation between nced expression and plant drought tolerance, studies to date have failed to identify the impact of AMF on the dynamics of ABA synthesis. In addition, considering the specific role of ABA in the development of the complete arbuscule and its functionality during AM symbiosis (Herrera-Medina et al. 2007), it is of special interest to study the putative influences of AM symbiosis on ABA signaling pathway to improve plant drought tolerance. Additionally, as one of the AMF strategies in helping plants cope with water deficit, the extraradical mycelium of AMF can enter fine soil pores and enhance water transport to plants (Khalvati et al. 2005). Our previous work has suggested that the functional aquaporins (GintAQPF1 and GintAQPF2) potentially mediated water uptake by host plants (Li et al. 2013). An AMF 14-3-3 protein may be involved in signaling pathways in AMF (Porcel et al. 2006b) and activities of GintAQPF1 and GintAQPF2. Uncovering the plant regulators triggering AMF 14-3-3 protein and aquaporins could lead to a better understanding of the drought tolerance of AM associates.

In this context, we performed a split-root experiment, in which two parts of the plant roots were subjected to independent treatments with drought stress and mycorrhizal inoculation. By comparing the impact of partial and overall inoculation on plant drought tolerance, we can elucidate whether the AMF Rhizophagus intraradices functions locally or systemically. Actually, Bárzana et al. (2015) have reported that AM effects occurred in both local and systemic ways on accumulation of osmolytes and plasma membrane intrinsic proteins (PIPs) and on antioxidant systems in maize plants. However, the underlying regulatory mechanisms are largely unknown so far. Here, we further studied the effects of the heterogeneous drought stresses on the expression profiles of the genes from both roots and $R$. intraradices to shed light on the crosstalk between host plants and AMF. We recorded plant physiological parameters including dry weight, relative water content, phosphorus $(\mathrm{Pi})$ concentration, and root $\mathrm{ABA}$ concentration, and assessed expression of 15 genes 
from maize roots which are relevant to drought tolerance, including five genes involved in ABA biosynthesis ( $D X S, D X R, P D S$, $Z D S$, and $A O$ ), IPS, 14-3GF, seven ABA-dependent PIPS (RuizLozano et al. 2009), and one gene encoding superoxide dismutase (SOD) (Jia et al. 2006). In addition to the above-described plant genes, we took into account three AMF genes including a 14-3-3 gene (Ri14-3-3), GintAQPF1, and GintAQPF2. The study was therefore aimed at revealing the regulatory roles of AMF in the ABA signaling pathway and plant drought tolerance, and also at identifying potential regulators that may play a role in the crosstalk between host plants and AMF under drought stress. We hypothesized that the synergistic responses of the symbiotic partners to drought stress may be activated through the ABA signaling pathway.

\section{Materials and methods}

\section{Biological materials and growth conditions}

Seeds of maize (Zea mays L.) 'B73' were surface-sterilized for $10 \mathrm{~min}$ by using $10 \% \mathrm{H}_{2} \mathrm{O}_{2}$, germinated, and transferred to containers containing autoclaved silica sand. After pregrowth for 2 weeks, uniform seedlings with six nodal roots were selected for the experiment. The growth medium was an autoclaved 4:9 (w/w) mixture of sand and soil ( $<2 \mathrm{~mm})$ collected from Duolun $\left(42^{\circ} 02^{\prime} \mathrm{N}, 116^{\circ} 17^{\prime} \mathrm{E}\right)$, Inner Mongolia, China (hereafter, "soil" is used to refer to this substrate) and inoculated or not with $R$. intraradices AH01 (c. 1200 spores per compartment) as described by Li et al. (2013). Before the experiment, basal nutrients with $25 \mathrm{mg} \mathrm{kg}^{-1} \mathrm{P}_{\mathrm{i}}, 120 \mathrm{mg} \mathrm{kg}^{-1}$ $\mathrm{K}$, and $90 \mathrm{mg} \mathrm{kg}^{-1} \mathrm{~N}$ were mixed into the soil, which had a $\mathrm{pH}$ of 8.17 (1:2.5 soil to water) and an extractable $\mathrm{P}_{\mathrm{i}}$ (with $0.5 \mathrm{M}$ $\mathrm{NaHCO}_{3}$ ) content of $6.73 \mathrm{mg} \mathrm{kg}^{-1}$.

The containers (14 cm in length, $10 \mathrm{~cm}$ in width, and $12 \mathrm{~cm}$ in height) were separated into two compartments of equal size by a solid PVC board with a thickness of $1 \mathrm{~mm}$ which was cemented into the container. The compartmented containers were carefully examined before the experiment to ensure that there was no leakage between compartments. The primary root of each plant was removed to aid the allocation of equal root portions into the two compartments (one plant per container, three nodal roots each compartment). In addition, the solid PVC board in the container was wedged into a vertical incision ( $c$. $1 \mathrm{~cm}$ ) of the stem base of the seedling so that emerging new roots were evenly distributed into each compartment.

In each compartment of the cultivation system, there were four treatments: well-watered (W) or droughtstressed (D), inoculated (M), or non-inoculated (nM) with $R$. intraradices. A full combination of treatments in two compartments resulted in a total of ten treatments, and four replicates were established for each treatment. There were four homogeneous treatments characterized by the same water and mycorrhizal status in both compartments (W/nM-W/nM, D/nM-D/nM, $\mathrm{W} / \mathrm{M}-\mathrm{W} / \mathrm{M}, \mathrm{D} / \mathrm{M}-\mathrm{D} / \mathrm{M})$ and six heterogeneous treatments differing either in soil water regime (W/nM-D/ $\mathrm{nM}, \mathrm{W} / \mathrm{M}-\mathrm{D} / \mathrm{M})$, mycorrhizal inoculation (W/nM-W/M, $\mathrm{D} / \mathrm{nM}-\mathrm{D} / \mathrm{M})$, or both mycorrhizal inoculation and water regime $(\mathrm{W} / \mathrm{M}-\mathrm{D} / \mathrm{nM}, \mathrm{W} / \mathrm{nM}-\mathrm{D} / \mathrm{M})$. The resulting 40 containers were set up in a completely randomized block design. After transplanting, the roots in all W compartments were exposed to $12 \%$ soil water content (SWC, by weight) equating to $c .70 \%$ field water capacity throughout the experiment. In all D compartments, $12 \% \mathrm{SWC}$ was maintained for 25 days, and then gradually decreased to $6 \%$ within 1 week, which was maintained for another 10 days before harvest. Daily evapotranspiration was estimated gravimetrically and compartments were watered to maintain the desired moisture content. The water loss from the split-root systems with nonuniform water treatments was estimated based on the water replacement needs of the containers with uniform water treatments. Considering lower estimated SWC in the W compartments whose counterpart compartments were subjected to D instead of W (Neumann et al. 2009), c. $10 \%$ of daily water depletion from those W compartments was supplemented additionally. Estimation of daily water needs for each compartment is shown in Supplementary Table 1. The SWC in individual root compartments was verified by using C-52 sample chambers coupled to a Wescor HR-33T Dew Point Microvoltmeter (Wescor, Logan, UT, USA).

The experiment was carried out in a controlled environment growth chamber at $700 \mu \mathrm{mol} \mathrm{m} \mathrm{s}^{-2}$ light intensity, $16 \mathrm{~h} / 8 \mathrm{~h}$ and $25: 20{ }^{\circ} \mathrm{C}$ (light/dark), and $70 \%$ relative humidity. Plants were harvested 42 days post-inoculation. Roots from each compartment and shoots were collected separately and thoroughly washed with distilled water. One gram fresh weight of roots from each compartment was stored at $-80^{\circ} \mathrm{C}$ for RNA processing and $\mathrm{ABA}$ concentration analysis. The relative water content was determined according to Ruiz-Lozano and Azcon (1997). One gram fresh weight of roots from each compartment was used for root staining and determination of mycorrhizal colonization rates ( $\mathrm{Li}$ et al. 2014). In brief, roots were cleared in $10 \%$ $\mathrm{KOH}$ and stained with $0.05 \%$ trypan blue in lactic acid $(v / v)$ to confirm the presence of fungal structures (intraradical mycelia, vesicles, and arbuscules). The mycorrhizal colonization was calculated according to the root segment frequency method and expressed as a percentage of the length of root segments containing AM fungal structures. Shoots and the rest of the roots were dried at $80{ }^{\circ} \mathrm{C}$ for $48 \mathrm{~h}$ to record dry weights.

\section{Analysis of $P_{i}$ concentration and root $A B A$ concentration}

For determination of $\mathrm{P}_{\mathrm{i}}$ concentration in shoots and roots from each compartment, about $0.2 \mathrm{~g}$ dried ground plant sample was digested in guaranteed reagent $\mathrm{HNO}_{3}$ for $12 \mathrm{~h}$, followed 
by a microwave-accelerated reaction for $35 \mathrm{~min}$ in a Microwave-Accelerated Reaction System (Mars, CEM Corp., USA). After the digested solution was diluted, solution $\mathrm{P}_{\mathrm{i}}$ concentrations were measured by inductively coupled plasma atomic emission spectrometry (ICP-AES, Prodigy, Leeman Labs, USA). Root ABA concentration was quantified using a plant ABA ELISA kit (Rapidbio, West Hills, USA). In brief, root samples were immersed in $2 \mathrm{ml}$ distilled water at $4{ }^{\circ} \mathrm{C}$ in the dark for $24 \mathrm{~h}$. After centrifugation at $3000 \times \mathrm{g}$ for $2 \mathrm{~min}$, the supernatant was used for a horseradish peroxidase (HRP)-tetramethyl benzidine (TMB) chromogenic assay according to the manufacturer's instructions. Absorbance was recorded at $450 \mathrm{~nm}$ using a Spectra Microplate Reader (SPECTRA max190, MD, USA).

\section{Gene expression analysis}

Total RNA from roots was isolated by using Trizol (Invitrogen, Grand Island, NY, USA) with a DNase treatment. cDNAs were synthesized from the RNA samples using a PrimeScript ${ }^{\circledR}$ RT Reagent Kit (TAKARA Biotechnology Co. Ltd, Dalian, China) following the manufacturer's instructions. Quantitative real-time PCR (qRT-PCR) was performed on the cDNAs with at least three independent biological replicates and three technical replicates for each biological replicate in a Bio-Rad iQ5 Optical system (Bio-Rad, Hercules, CA, USA), monitored by SYBR Green I fluorescence (TAKARA Biotechnology Co. Ltd). Twenty-five microliters of reaction medium contained SYBR Green I PCR Mix, $400 \mathrm{nM}$ of genespecific primers, and the cDNA templates diluted 10-fold. For plant and AMF gene expression analysis, 2 and $4 \mu \mathrm{l}$ of the diluted cDNAs were respectively added to the reaction medium. The qRT-PCR primers that we designed are listed in Supplementary Table 2. Negative control reactions (using RNA or water instead of cDNA) were included to avoid genomic DNA contamination and to exclude formation of primer-dimer. The qRT-PCR program consisted of an initial step at $95^{\circ} \mathrm{C}$ for $30 \mathrm{~s}$, followed by 40 cycles of denaturation at $95^{\circ} \mathrm{C}$ for $5 \mathrm{~s}$, annealing for $45 \mathrm{~s}$ and extension at $72{ }^{\circ} \mathrm{C}$ for $30 \mathrm{~s}$ and one cycle of $60 \mathrm{~s}$ at $72{ }^{\circ} \mathrm{C}$. The annealing temperatures are shown in Supplementary Table 2. To test the amplification specificity, melting curves were produced according to the following program: $10 \mathrm{~s}$ at $70{ }^{\circ} \mathrm{C}$, and heating to $100{ }^{\circ} \mathrm{C}$ at a rate of $0.5^{\circ} \mathrm{C} \mathrm{s}^{-1}$, and data were continuously collected. The data were analyzed by the $2^{-\Delta \Delta \mathrm{Ct}}$ method (Pfaffl 2001). Normalization of the results was achieved using both glyceraldehyde phosphate dehydrogenase (GAPDH) and alpha tubulin genes as plant internal controls and using both Gint18S rRNA (Gónzalez-Guerrero et al. 2005) and translation elongation factor (TEF) genes as fungal internal controls. Because the two plant or fungal internal controls yielded the same results, GAPDH and Gint18S rRNA were selected.

\section{Statistical analysis}

Data were expressed as the mean $\pm \mathrm{SD}$ of observations from independent replicates. Effects of AMF on the whole root system were determined by analyzing the homogeneous treatments. Total root dry weight was recorded as the sum of measurements from two individual compartments, whereas the data for the remaining parameters were calculated as means of the measurements. Two-way ANOVA was performed to compare mycorrhizal inoculation and soil water regime for data on all parameters except for AMF colonization and AMF gene expression by using SPSS (version 13.0, SPSS Inc., USA). Following ANOVA, Duncan's multiple-range test (Duncan 1955) was performed to make comparisons between treatments. When there were no significant interactions, data were subjected to $t$ test in Microsoft $\circledast$ Excel 2007 to test for significant differences between treatments.

For analyzing the treatment effects on colonization rate, expression of GintAQPF1, GintAQPF2, and Ri 14-3-3, one-way ANOVA was first conducted with "water" as the main factor, followed by Duncan's multiple-range test to test for the effects of water regime on the assayed parameters in the same compartment (local effect), then two-way ANOVA was performed, followed by Duncan's multiple-range test to evaluate the effects of both mycorrhizal inoculation and water regime in one compartment on the assayed parameters in the counterpart compartment (systemic effect). Two-way ANOVA was performed only for the inoculated and wellwatered (W/M) or drought-stressed (D/M) target compartments, as the values of the assayed parameters were not available in the $\mathrm{nM}$ compartments.

For analyzing the treatment effects on shoot dry weight, shoot relative water content, and shoot $\mathrm{P}_{\mathrm{i}}$ concentration, oneway ANOVA was first performed with "treatment" as the main factor, followed by Duncan's multiple-range test to examine the significance of differences between the treatments. In addition, two-way ANOVA was conducted with both "water" and "inoculation" as the main factors, followed by Duncan's multiple-range test to evaluate differences in the assayed parameters between homogeneous and heterogeneous treatments.

The data of root characteristics were divided into four clusters, i.e., non-inoculated in the well-watered compartment (W/nM), non-inoculated in the drought-stressed compartment (D/nM), W/M, and D/M. Two-way ANOVA was separately performed for each cluster, followed by Duncan's multiplerange test to evaluate systemic effects of the main factors ("water" and "inoculation") in one compartment on root dry weight, root relative water content, $\mathrm{P}_{\mathrm{i}}$ concentration, $\mathrm{ABA}$ concentration, and expression of selected genes in roots in the counterpart compartment.

For evaluating the systemic effects of mycorrhizal inoculation on expression of the considered plant genes, all possible combinations of $\mathrm{M}$ versus $\mathrm{nM}$ treatments were taken into 
account. Locally regulated genes were identified when genes in roots from the compartment adjacent to an $\mathrm{M}$ compartment exhibited a similar expression level in comparison with $\mathrm{nM}$ controls (mycorrhizal inoculation in one compartment showed no influence on gene expression in roots from the counterpart compartment), whereas a significantly altered expression level as affected by $\mathrm{M}$ was considered a systemically regulated gene. The data were subjected to $t$ test in Microsoft ${ }^{\circledR}$ Excel 2007 to identify such significant differences between treatments.

\section{Results}

\section{AM colonization}

Generally, AM colonization was lower in the homogeneous well-watered (W-W) and drought-stressed (D-D) treatments than that in the heterogeneous treatments (W-D) (Fig. 1; Table 1). Under the same water regime (W-W, D-D or W-D), no significant differences were found in mycorrhizal colonization between the inoculated treatments.

\section{Plant growth}

Compared with W-W, W-D did not affect shoot dry weight regardless of AM inoculation. However, D-D significantly decreased shoot dry weight when the roots were subjected to both homogeneous $\mathrm{nM}$ treatment (nM-nM) and heterogeneous inoculation treatment (nM-M). Homogeneous M treatment (M-M) alleviated the negative effects of D-D, leading to non-significant differences in shoot dry weight between W-D

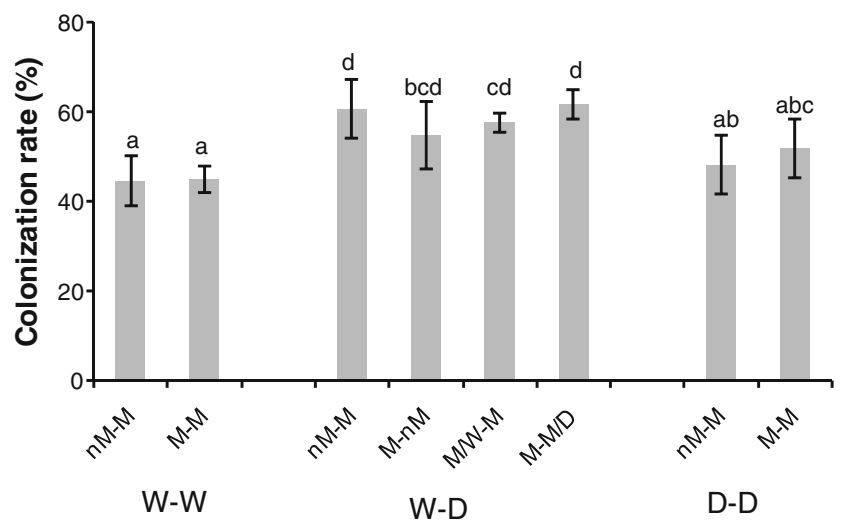

Fig. 1 Mycorrhizal colonization rates of maize plants cultivated in a split-root system. Each compartment of the cultivation system was either inoculated $(M)$ or not $(n M)$ with $R$. intraradices and subjected to wellwatered $(W)$ condition or drought stress $(D)$. Only inoculated compartments were analyzed. $M / W-M$ and $M-M / D$ indicate the inoculated compartments in W/M-D/M are under well-watered condition and under drought stress, respectively. The error bars represent SD $(n=4)$. Bars topped by the same lowercase letter do not differ significantly at $P<0.05$ by Duncan's multiple-range test
Table 1 Results of two-way ANOVA showing the statistical significance of the effects of mycorrhizal inoculation and soil water regime in one compartment (compartment 1 ) on root colonization in the counterpart inoculated compartment (compartment 2)

\begin{tabular}{lll}
\hline $\begin{array}{l}\text { Compartment } 1 \\
\text { Treatment clusters }\end{array}$ & $\begin{array}{l}\text { Compartment 2 } \\
\text { Factors }\end{array}$ & Colonization \\
\hline W/M & Soil water (SW) & $* *$ \\
& Inoculation (I) & ns \\
& SW $\times$ I & ns \\
D/M & Soil water (SW) & $*$ \\
& Inoculation (I) & ns \\
& SW $\times$ I & ns \\
\hline
\end{tabular}

$M$ "inoculated", $W$ "well-watered," $D$ "drought-stressed"

$* P<0.05 ; * * P<0.01 ;$ ns, not significant (ANOVA output)

and D-D (Fig. 2a; Table 2). Under the same water regime, M$\mathrm{M}$ significantly increased shoot dry weight as compared with nM-nM. By contrast, the significant influences of nM-M on shoot dry weight were observed only under D-D condition, where there were significant differences in shoot dry weights between nM-M and M-M (Fig. 2a; Table 2).

Under W-D condition, root dry weight decreased considerably only for the half directly subjected to drought, except for the $\mathrm{D} / \mathrm{nM}$ roots in $\mathrm{M} / \mathrm{W}-\mathrm{D} / \mathrm{nM}$. It is remarkable that under D-D condition root dry weight significantly decreased only when the root compartment remained uninoculated as compared with W-D (Table 3). Under the same water condition, although the inoculated roots showed higher dry weight than the non-inoculated ones, no significant influence of inoculation in one compartment on root dry weight in the counterpart compartment was observed (Table 3 and Supplementary Table 3).

\section{Plant water status}

Compared with W-W, W-D did not affect shoot relative water content, except for W/M-D/M. However, D-D significantly decreased shoot relative water content regardless of the presence of $R$. intraradices (Fig. 2b; Table 2). Only under D-D condition, both nM-M and M-M displayed a noticeable increase in shoot relative water content in comparison with nM-nM, and no significant differences in shoot relative water content between $\mathrm{nM}-\mathrm{M}$ and $\mathrm{M}-\mathrm{M}$ were observed (Fig. 2b; Table 2).

For root relative water content, there was no significant difference between the two compartments with heterogeneous treatments. W-D significantly decreased root relative water content only in $\mathrm{nM}$ plants. D-D resulted in significantly lower root relative water content compared with W-D when plants remained uninoculated or were partially inoculated with $R$. intraradices (Table 3). On the other hand, under W-D or D-D, root 

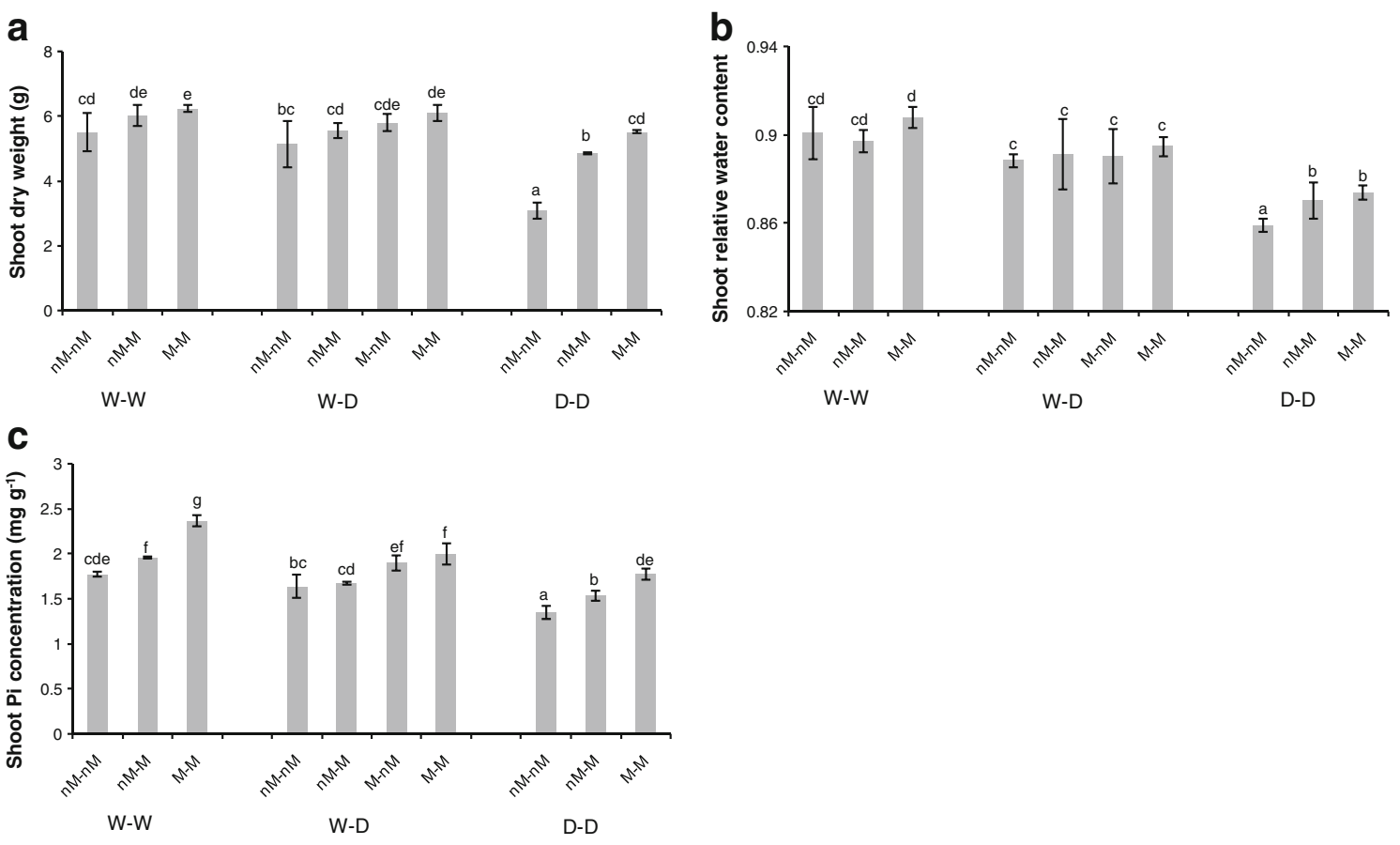

Fig. 2 Shoot dry weight (a), shoot relative water content (b), and shoot phosphorus $\left(\mathrm{P}_{\mathrm{i}}\right)$ concentration $(\mathbf{c})$ of maize plants cultivated in a split-root system. Each compartment of the cultivation system was either inoculated $(M)$ or not $(n M)$ with $R$. intraradices and subjected to well-watered $(W)$

condition or drought stress $(D)$. The error bars represent $\mathrm{SD}(n=4)$. Bars topped by the same lowercase letter do not differ significantly at $P<0.05$ by Duncan's multiple-range test

relative water content was significantly enhanced by both nM-M and M-M in comparison with nM-nM. The nM-M combined with D-D treatment was an exception. The significantly positive effect of $\mathrm{M}-\mathrm{M}$ on root relative water content was not observed when compared with nM-M (Table 3 and Supplementary Table 3).

\section{Plant $P_{i}$ nutrition}

Compared with W-W, W-D significantly decreased shoot $\mathrm{P}_{\mathrm{i}}$ concentration in both W/nM-D/M and W/M-D/M. The comparison of W-D with D-D indicated that well-watering in one compartment systemically increased shoot $\mathrm{P}_{\mathrm{i}}$ concentration.

Table 2 Results of two-way ANOVA showing the statistical significance of the effects of mycorrhizal inoculation and soil water regime on shoot dry weight, relative water content, and phosphorus $\left(\mathrm{P}_{\mathrm{i}}\right)$ concentration in response to homogeneous and heterogeneous treatments in split root systems

\begin{tabular}{|c|c|c|c|c|}
\hline & Factors & $\begin{array}{l}\text { Shoot dry weight } \\
\text { (g/plant) }\end{array}$ & $\begin{array}{l}\text { Shoot relative water } \\
\text { content }\end{array}$ & $\begin{array}{l}\text { Shoot } \mathrm{P}_{\mathrm{i}} \text { concentration } \\
\left(\mathrm{mg} \mathrm{g}^{-1}\right)\end{array}$ \\
\hline \multirow{10}{*}{$\begin{array}{l}\text { All } \\
\text { treat- } \\
\text { ments }\end{array}$} & $\begin{array}{l}\text { Soil water } \\
\quad \text { (SW) }\end{array}$ & $* *$ & $* *$ & $* *$ \\
\hline & Factor levels & & & \\
\hline & $\mathrm{W}-\mathrm{W}$ & $\mathrm{b}$ & $\mathrm{c}$ & $\mathrm{c}$ \\
\hline & D-D & $\mathrm{a}$ & $\mathrm{a}$ & $\mathrm{a}$ \\
\hline & W-D & $\mathrm{b}$ & $\mathrm{b}$ & $\mathrm{b}$ \\
\hline & $\begin{array}{l}\text { Inoculation } \\
\text { (I) } \\
\text { Factor levels }\end{array}$ & $* *$ & ns & $* *$ \\
\hline & $\mathrm{nM}-\mathrm{nM}$ & $\mathrm{a}$ & $\mathrm{a}$ & $\mathrm{a}$ \\
\hline & M-M & $\mathrm{c}$ & $\mathrm{a}$ & $\mathrm{c}$ \\
\hline & nM-M & $\mathrm{b}$ & $\mathrm{a}$ & $\mathrm{b}$ \\
\hline & $\mathrm{SW} \times \mathrm{I}$ & $* *$ & ns & ns \\
\hline
\end{tabular}

$n M$ "non-inoculated," $M$ “inoculated," $W$ “well-watered," $D$ "drought-stressed"

$* P<0.05 ; * * P<0.01$; ns, not significant (ANOVA output). The same lowercase letter within a column indicates no significant difference at $P<0.05$ between treatments 
Table 3 Results of two-way ANOVA showing the statistical significance of the effects of mycorrhizal inoculation and soil water regime in one compartment (compartment 1) on root dry weight (RDW), and root relative water content (RRWC), $\mathrm{P}_{\mathrm{i}}$ concentration $\left(\mathrm{R}-\mathrm{P}_{\mathrm{i}}\right)$, and abscisic acid (ABA) concentration (R-ABA) in the counterpart compartment (compartment 2)

\begin{tabular}{|c|c|c|c|c|c|}
\hline $\begin{array}{l}\text { Compartment } 1 \\
\text { Treatment clusters }\end{array}$ & $\begin{array}{l}\text { Compartment } 2 \\
\text { Factors }\end{array}$ & RDW (g) & RRWC & $\mathrm{R}-\mathrm{P}_{\mathrm{i}}\left(\mathrm{mg} \mathrm{g}^{-1}\right)$ & $\mathrm{R}-\mathrm{ABA}\left(\mathrm{ng} \mathrm{g}^{-1} \mathrm{FW}\right)$ \\
\hline \multirow[t]{8}{*}{$\mathrm{W} / \mathrm{nM}$} & $\mathrm{W} / \mathrm{nM}$ & $0.64^{\mathrm{a}}$ & $0.88 \#$ & 1.01 & 37.97 \\
\hline & $\mathrm{W} / \mathrm{M}$ & 0.68 & 0.90 & 0.99 & 37.55 \\
\hline & $\mathrm{D} / \mathrm{nM}$ & 0.57 & 0.80 & 1.13 & $47.26 \#$ \\
\hline & $\mathrm{D} / \mathrm{M}$ & 0.60 & $0.88 \mathrm{~A}$ & 0.98 & 42.29\# \\
\hline & Significance $^{\mathrm{b}}$ of & & & & \\
\hline & Soil water (SW) & ns & $*$ & ns & $* *$ \\
\hline & Inoculation (I) & ns & * & ns & $\mathrm{ns}$ \\
\hline & $\mathrm{SW} \times \mathrm{I}$ & ns & ns & ns & ns \\
\hline \multirow[t]{8}{*}{$\mathrm{D} / \mathrm{nM}$} & $\mathrm{W} / \mathrm{nM}$ & $0.50 \#$ & $0.80 \#$ & 0.98 & $48.81 \mathrm{~A}$ \\
\hline & $\mathrm{W} / \mathrm{M}$ & $0.57 \#$ & $0.87 \mathrm{~A}$ & 1.12 & 41.31 \\
\hline & $\mathrm{D} / \mathrm{nM}$ & 0.37 & 0.73 & 1.02 & 53.30\#A \\
\hline & $\mathrm{D} / \mathrm{M}$ & 0.46 & 0.77 & 0.97 & $46.28 \#$ \\
\hline & Significance of & & & & \\
\hline & Soil water (SW) & $*$ & $* *$ & ns & $* *$ \\
\hline & Inoculation (I) & ns & $*$ & ns & $* *$ \\
\hline & $\mathrm{SW} \times \mathrm{I}$ & ns & ns & ns & ns \\
\hline \multirow[t]{8}{*}{$\mathrm{W} / \mathrm{M}$} & $\mathrm{W} / \mathrm{nM}$ & 0.78 & 0.89 & $1.41 \mathrm{a}$ & 39.57 \\
\hline & $\mathrm{W} / \mathrm{M}$ & 0.75 & 0.90 & $1.70 \mathrm{~b}$ & 39.36 \\
\hline & $\mathrm{D} / \mathrm{nM}$ & 0.70 & 0.90 & $1.43 \mathrm{a}$ & 39.51 \\
\hline & $\mathrm{D} / \mathrm{M}$ & 0.77 & 0.90 & $1.50 \mathrm{a}$ & 43.79 \\
\hline & Significance of & & & & \\
\hline & Soil water (SW) & ns & ns & ns & $\mathrm{ns}$ \\
\hline & Inoculation (I) & ns & ns & $* *$ & ns \\
\hline & $\mathrm{SW} \times \mathrm{I}$ & ns & ns & $*$ & $\mathrm{~ns}$ \\
\hline \multirow[t]{8}{*}{$\mathrm{D} / \mathrm{M}$} & $\mathrm{W} / \mathrm{nM}$ & $0.62 \#$ & $0.88 \#$ & $1.39 \#$ & 44.01 \\
\hline & W/M & $0.67 \#$ & $0.90 \#$ & $1.41 \#$ & 44.16 \\
\hline & $\mathrm{D} / \mathrm{nM}$ & 0.53 & 0.78 & 1.16 & 45.03 \\
\hline & $\mathrm{D} / \mathrm{M}$ & 0.60 & $0.83 \mathrm{~A}$ & 1.21 & 44.20 \\
\hline & Significance of & & & & \\
\hline & Soil water (SW) & $*$ & $* *$ & $* *$ & ns \\
\hline & Inoculation (I) & ns & $*$ & ns & ns \\
\hline & $\mathrm{SW} \times \mathrm{I}$ & ns & ns & ns & ns \\
\hline
\end{tabular}

$n M$ “non-inoculated," $M$ “inoculated," $W$ “well-watered," $D$ “drought-stressed”

${ }^{a}$ Duncan's multiple-range test was performed across all treatments when interactions were significant, and $t$ test was performed to compare differences between treatments when there were no significant interactions. The same lowercase letter within a column indicates no significant difference at $P<0.05$ between treatments. \# and A indicate significant $(P<0.05)$ effects of the main factor "water" and "inoculation" in one compartment on the assayed parameters in the counterpart compartment, respectively

${ }^{\mathrm{b}}$ ANOVA output: $* P<0.05 ; * * P<0.01 ; \mathrm{ns}$, not significant
Under the same water condition, plants treated with both nM$\mathrm{M}$ and $\mathrm{M}-\mathrm{M}$ displayed significantly higher shoot $\mathrm{P}_{\mathrm{i}}$ concentration than nM-nM, except for plants grown in W/nM-D/M (Fig. 2c; Table 2). M-M led to significantly higher shoot $\mathrm{P}_{\mathrm{i}}$ concentration than $\mathrm{nM}-\mathrm{M}$, but W/M-D/nM was an exception (Fig. 2c; Table 2).

Neither mycorrhizal inoculation nor water regime in one compartment significantly affected root $\mathrm{P}_{\mathrm{i}}$ concentration in its counterpart compartment where roots were uninoculated (Table 3). However, significantly lower $\mathrm{P}_{\mathrm{i}}$ concentration of the inoculated roots in W-D and D-D was found as compared with $\mathrm{W}-\mathrm{W}$ and $\mathrm{W}-\mathrm{D}$, respectively, with an exception of W/nM-W/M (Table 3 and Supplementary Table 3). Surprisingly, only marginal differences in root $\mathrm{P}_{\mathrm{i}}$ concentration among all inoculated compartments were observed under either W-D or D-D treatment (Table 3). 


\section{Root ABA concentration}

In this study, we focused on the ABA concentration in roots to examine its potential role in the crosstalk between the host plant and AM fungus. There was no significant difference in ABA concentration between the two compartments with heterogeneous treatments (Table 3). Remarkably, neither mycorrhizal inoculation nor water regime in one compartment influenced root ABA concentration in the counterpart inoculated compartment, while for ABA concentration in the noninoculated roots, significant regulation was recorded (Table 3). W-D and D-D displayed significantly higher root ABA concentration compared with W-W, except for W/M-D/ nM (Table 3 and Supplementary Table 3). A significant difference also was found between W/nM-D/nM and D/nM-D/ $\mathrm{nM}$, and between W/M-D/nM and D/nM-D/M. On the other hand, mycorrhizal inoculation in either one or both compartments significantly down-regulated $\mathrm{ABA}$ concentration in the whole root system under treatments of W-D and D-D (Table 3 and Supplementary Table 3).

\section{Plant genes}

We obtained the sequences of relevant plant genes, annotated by Gramene, from the B73 genomic database (http://maizegdb. org/) and used tblastn in the database of the National Center for Biotechnology Information (NCBI) to confirm they are single-copy.

To determine the potential role of AMF in regulation of plant ABA synthesis and $\mathrm{ABA}$ signal transduction, gene expression analysis was first performed using data from homogeneous treatments. Under well-watered conditions, except for $D X R, P D S, Z D S, 14-3 G F, Z m P I P 1 ; 1$, and SOD, the rest of the selected genes were all significantly up-regulated by mycorrhizal inoculation (Supplementary Tables 4 and 5). Drought significantly promoted isoprenoid metabolism and ABA biosynthesis regardless of mycorrhizal inoculation (Supplementary Table 4). For the genes involved in ABA signal transduction, drought significantly suppressed their expression in $\mathrm{nM}$ plants, while inducing gene expression in $\mathrm{AM}$ plants (Supplementary Tables 4 and 5). It was noticeable that AM plants exhibited remarkably increased expression of IPS, 14-3GF, SOD, and PIPs, and decreased $A O$ expression as compared with nM plants under drought stress (Supplementary Tables 4 and 5).

To ascertain if AM affects the whole or only the half root system subjected to drought, expression patterns of the observed genes under heterogeneous situations were investigated. As compared to W/nM-W/nM, although W/M in one compartment did not systemically up-regulate the majority of genes in the roots in its counterpart $\mathrm{W} / \mathrm{nM}$ compartment, the systemic induction of IPS should not be ignored (Tables 4 and 5). However, under homogeneous drought stress, all the genes involved in ABA signal transduction and responsive to $\mathrm{ABA}$ were systemically regulated in response to heterogeneous mycorrhizal inoculation, characterized by up-regulation of gene expression in the non-inoculated compartment as compared to $\mathrm{D} / \mathrm{nM}-\mathrm{D} / \mathrm{nM}$, and down-regulation in the inoculated compartment, compared with D/M-D/M (Tables 4 and 5). The downregulated genes also included $D X S$ (Table 4).

The comparison of W/M-D/nM with W/nM-D/nM indicated that mycorrhizal colonization systemically suppressed $A O$ and induced all the genes involved in ABA signal transduction and responsive to $\mathrm{ABA}$ in the roots from the $\mathrm{D} / \mathrm{nM}$ compartment, except for $S O D$ clustered in the local-response class. For the inoculated compartment in W/M-D/nM, however, the expression pattern of the selected genes was indicative of a general local response, when compared with gene expression in W/M-W/M, except for ZmPIP2; 1 and ZmPIP2;6 clustered in the systemic-induction class. As compared to W/M-D/M, a combination of mycorrhizal inoculation and drought stress systemically stimulated the expression of IPS and 14-3GF in the roots from the W/M compartment (Tables 4 and 5).

In the $\mathrm{W} / \mathrm{nM}-\mathrm{D} / \mathrm{M}$ treatment, the roots in the $\mathrm{W} / \mathrm{nM}$ compartment displayed remarkably higher expression of IPS and PIPs except ZmPIP1;1 compared with that in $\mathrm{W} / \mathrm{nM}-\mathrm{W} / \mathrm{nM}$. In addition to IPS and PIPs, $14-3 G F$ in the $\mathrm{W} / \mathrm{nM}$ roots showed significantly higher expression in W/nM-D/M than in $\mathrm{W} / \mathrm{nM}-\mathrm{D} / \mathrm{nM}$. In the inoculated compartment of W/nM-D/ $\mathrm{M}$, the $\mathrm{W} / \mathrm{nM}$ treatment systemically suppressed the expression of DXS and PIPs except ZmPIP1;1, ZmPIP1;2, and $Z m P I P 1 ; 5$, when compared with D/M-D/M. The comparison of W/nM-D/M with W/M-D/M demonstrated that the W/M treatment did not affect the expression of all selected genes in the $\mathrm{D} / \mathrm{M}$ roots (Tables 4 and 5).

\section{AMF genes}

Based on the 14-3-3 gene screened from the genome of R. irregularis DAOM 197198 (Lin et al. 2014), Ri 14-3-3 was cloned from $R$. intraradices AH01. The similarity of the amplified fragments between $R$. intraradices AH01 and R. irregularis DAOM 197198 was $98 \%$, which was confirmed by sequencing.

The expression profiles of the three fungal genes among all treatments exhibited similar trends (Fig. 3). Generally, the lowest gene expression was found in the W/M roots in $\mathrm{W} / \mathrm{nM}-\mathrm{W} / \mathrm{M}, \mathrm{W} / \mathrm{M}-\mathrm{W} / \mathrm{M}$, and $\mathrm{W} / \mathrm{M}-\mathrm{D} / \mathrm{nM}$, whereas the highest expression was identified in the $\mathrm{D} / \mathrm{M}$ roots in $\mathrm{D} / \mathrm{nM}$ $\mathrm{D} / \mathrm{M}$ and $\mathrm{D} / \mathrm{M}-\mathrm{D} / \mathrm{M}$. Intermediate gene expression was observed in the $\mathrm{D} / \mathrm{M}$ roots in $\mathrm{W} / \mathrm{nM}-\mathrm{D} / \mathrm{M}$ and $\mathrm{W} / \mathrm{M}-\mathrm{D} / \mathrm{M}$ and the W/M roots in W/M-D/M. The three genes in the W/M roots were significantly up-regulated only when the roots in the counterpart compartment were subjected to D/M treatment. A significantly higher expression of the genes in the 
Table 4 Results of two-way ANOVA showing the statistical significance of the effects of mycorrhizal inoculation and soil water regime in one compartment (compartment 1) on relative expression of $A O, D X S, D X R, P D S$, $Z D S, I P S, 14-3 G F$, and $S O D$ in maize roots in the counterpart compartment (compartment 2)

\begin{tabular}{|c|c|c|c|c|c|c|c|c|c|}
\hline $\begin{array}{l}\text { Compartment } 1 \\
\text { Treatment } \\
\text { clusters }\end{array}$ & $\begin{array}{l}\text { Compartment } \\
2 \\
\text { Factors }\end{array}$ & $A O$ & $D X S$ & $D X R$ & $P D S$ & $Z D S$ & IPS & $\begin{array}{l}14- \\
3 G F\end{array}$ & $S O D$ \\
\hline \multirow[t]{8}{*}{$\mathrm{W} / \mathrm{nM}$} & $\mathrm{W} / \mathrm{nM}$ & $0.34^{\mathrm{a}}$ & 0.13 & 0.11 & 0.16 & 0.06 & $0.18 \mathrm{a}$ & $0.18 \mathrm{~b}$ & 0.31 \\
\hline & W/M & 0.25 & 0.17 & 0.14 & 0.18 & 0.06 & $0.28 \mathrm{~b}$ & $0.15 b$ & 0.35 \\
\hline & $\mathrm{D} / \mathrm{nM}$ & 0.44 & 0.16 & 0.12 & 0.16 & 0.06 & $0.22 \mathrm{a}$ & $0.08 \mathrm{a}$ & 0.37 \\
\hline & $\mathrm{D} / \mathrm{M}$ & $0.44 \#$ & 0.15 & 0.16 & 0.18 & 0.07 & $0.36 \mathrm{c}$ & $0.20 \mathrm{~b}$ & 0.35 \\
\hline & $\begin{array}{l}\text { Significance } \\
\text { of }\end{array}$ & & & & & & & & \\
\hline & $\begin{array}{l}\text { Soil water } \\
\text { (SW) }\end{array}$ & $* *$ & ns & ns & ns & ns & $* *$ & ns & ns \\
\hline & Inoculation (I) & ns & ns & ns & ns & ns & $* *$ & $*$ & ns \\
\hline & $\mathrm{SW} \times \mathrm{I}$ & ns & ns & $\mathrm{ns}$ & $\mathrm{ns}$ & ns & $*$ & $* *$ & ns \\
\hline \multirow[t]{8}{*}{$\mathrm{D} / \mathrm{nM}$} & $\mathrm{W} / \mathrm{nM}$ & $0.80 \mathrm{~A}$ & 0.32 & 0.35 & 0.32 & 0.08 & $0.26 \#$ & $0.08 \#$ & $0.44 \mathrm{~b}$ \\
\hline & $\mathrm{W} / \mathrm{M}$ & 0.60 & 0.38 & 0.42 & 0.33 & 0.11 & $0.41 \mathrm{~A}$ & $0.26 \# \mathrm{~A}$ & $0.48 \mathrm{bc}$ \\
\hline & $\mathrm{D} / \mathrm{nM}$ & 0.84 & $0.46 \#$ & 0.42 & 0.35 & 0.10 & 0.09 & 0.02 & $0.16 \mathrm{a}$ \\
\hline & $\mathrm{D} / \mathrm{M}$ & $0.77 \#$ & 0.39 & 0.37 & 0.35 & 0.08 & $0.36 \mathrm{~A}$ & $0.17 \mathrm{~A}$ & $0.54 \mathrm{c}$ \\
\hline & Significance of & & & & & & & & \\
\hline & $\begin{array}{l}\text { Soil water } \\
\text { (SW) }\end{array}$ & $*$ & $*$ & ns & ns & ns & $* *$ & $* *$ & $* *$ \\
\hline & Inoculation (I) & $* *$ & ns & ns & ns & ns & $* *$ & $* *$ & $* *$ \\
\hline & $\mathrm{SW} \times \mathrm{I}$ & ns & ns & ns & $\mathrm{ns}$ & $\mathrm{ns}$ & ns & ns & $* *$ \\
\hline \multirow[t]{8}{*}{$\mathrm{W} / \mathrm{M}$} & $\mathrm{W} / \mathrm{nM}$ & 0.57 & 0.18 & 0.16 & 0.24 & 0.08 & $0.26 \mathrm{a}$ & 0.22 & 0.33 \\
\hline & $\mathrm{W} / \mathrm{M}$ & 0.56 & 0.24 & 0.15 & 0.23 & 0.08 & $0.27 \mathrm{a}$ & 0.25 & 0.33 \\
\hline & $\mathrm{D} / \mathrm{nM}$ & 0.52 & 0.22 & 0.21 & 0.20 & 0.08 & $0.27 \mathrm{a}$ & 0.24 & 0.37 \\
\hline & $\mathrm{D} / \mathrm{M}$ & 0.56 & 0.21 & 0.21 & 0.24 & 0.09 & $0.35 b$ & $0.35 \# \mathrm{~A}$ & 0.37 \\
\hline & Significance of & & & & & & & & \\
\hline & $\begin{array}{l}\text { Soil water } \\
\text { (SW) }\end{array}$ & ns & ns & ns & ns & ns & $*$ & $*$ & ns \\
\hline & Inoculation (I) & ns & ns & ns & ns & ns & $*$ & $* *$ & ns \\
\hline & $\mathrm{SW} \times \mathrm{I}$ & ns & ns & $\mathrm{ns}$ & ns & ns & $*$ & ns & ns \\
\hline \multirow[t]{8}{*}{$\mathrm{D} / \mathrm{M}$} & $\mathrm{W} / \mathrm{nM}$ & 0.60 & $0.38 \mathrm{a}$ & 0.37 & 0.41 & 0.12 & $0.56 \mathrm{~b}$ & $0.49 \mathrm{~b}$ & 0.60 \\
\hline & $\mathrm{W} / \mathrm{M}$ & 0.58 & $0.31 \mathrm{a}$ & 0.45 & 0.39 & 0.09 & $0.56 \mathrm{~b}$ & $0.56 \mathrm{~b}$ & 0.60 \\
\hline & $\mathrm{D} / \mathrm{nM}$ & $0.71 \#$ & $0.32 \mathrm{a}$ & 0.44 & 0.42 & 0.11 & $0.30 \mathrm{a}$ & $0.14 \mathrm{a}$ & 0.51 \\
\hline & $\mathrm{D} / \mathrm{M}$ & 0.64 & $0.49 \mathrm{~b}$ & 0.50 & 0.41 & 0.12 & $0.63 b$ & $0.62 b$ & 0.63 \\
\hline & Significance of & & & & & & & & \\
\hline & $\begin{array}{l}\text { Soil water } \\
\text { (SW) }\end{array}$ & $*$ & ns & ns & ns & ns & $*$ & $*$ & ns \\
\hline & Inoculation (I) & ns & ns & ns & ns & ns & $* *$ & $* *$ & ns \\
\hline & $\mathrm{SW} \times \mathrm{I}$ & ns & $* *$ & ns & ns & ns & $* *$ & $* *$ & ns \\
\hline
\end{tabular}

$n M$ “non-inoculated," $M$ “inoculated," $W$ well-watered," $D$ “drought-stressed," $D X S$ 1-deoxy-Dxylulose 5-phosphate synthase 2, DXR 1-deoxy-D-xylolose 5-phosphate reductoisomerase, PDS phytoene desaturase, ZDS zeta-carotene desaturase, $A O$ aldehyde oxidase, IPS D-myo-inositol-3-phosphate synthase, 143GF 14-3-3-like protein GF14, SOD superoxide dismutase

${ }^{a}$ Duncan's multiple-range test was performed across all treatments when interactions were significant, and $t$ test was performed to compare differences between treatments when there were no significant interactions. The same lowercase letter within a column indicates no significant difference at $P<0.05$ between treatments. \# and A indicate significant $(P<0.05)$ effects of the main factor "water" and "inoculation" in one compartment on the gene expression in the counterpart compartment, respectively

${ }^{\mathrm{b}}$ ANOVA output: $* P<0.05 ; * * P<0.01$; ns, not significant 
Table 5 Results of two-way ANOVA showing the statistical significance of the effects of mycorrhizal inoculation and soil water regime in one compartment (compartment 1) on relative expression of ZmPIP1;1, ZmPIP1;2, ZmPIP1;5, ZmPIP 2; 1, ZmPIP 2;2, $Z m P I P 2 ; 5$, and $Z m P I P 2 ; 6$ in maize roots in the counterpart compartment (compartment 2)

\begin{tabular}{|c|c|c|c|c|c|c|c|c|}
\hline $\begin{array}{l}\text { Compartment } 1 \\
\text { Treatment } \\
\text { clusters }\end{array}$ & $\begin{array}{l}\text { Compartment } \\
2 \\
\text { Factors }\end{array}$ & $\begin{array}{l}Z m P I P \\
1 ; 1\end{array}$ & $\begin{array}{l}Z m P I P \\
1 ; 2\end{array}$ & $\begin{array}{l}Z m P I P \\
1 ; 5\end{array}$ & $\begin{array}{l}Z m P I P \\
2 ; 1\end{array}$ & $\begin{array}{l}Z m P I P \\
2 ; 2\end{array}$ & $\begin{array}{l}Z m P I P \\
2 ; 5\end{array}$ & $\begin{array}{l}Z m P I P \\
2 ; 6\end{array}$ \\
\hline \multirow[t]{8}{*}{$\mathrm{W} / \mathrm{nM}$} & $\mathrm{W} / \mathrm{nM}$ & 0.52 & $0.05 \mathrm{ab}$ & $1.36 \mathrm{a}$ & $0.35 \mathrm{a}$ & $0.04 \mathrm{a}$ & $0.44 \mathrm{a}$ & $0.16 b$ \\
\hline & $\mathrm{W} / \mathrm{M}$ & 0.54 & $0.05 b$ & $1.54 \mathrm{~b}$ & $0.43 b$ & $0.05 b$ & $0.51 \mathrm{~b}$ & $0.19 b$ \\
\hline & $\mathrm{D} / \mathrm{nM}$ & 0.47 & $0.04 \mathrm{a}$ & $1.25 \mathrm{a}$ & $0.29 \mathrm{a}$ & $0.03 \mathrm{a}$ & $0.39 \mathrm{a}$ & $0.10 \mathrm{a}$ \\
\hline & $\mathrm{D} / \mathrm{M}$ & 0.55 & $0.06 \mathrm{c}$ & $1.81 \mathrm{c}$ & $0.48 b$ & $0.05 b$ & $0.61 \mathrm{c}$ & $0.28 \mathrm{c}$ \\
\hline & $\begin{array}{l}\text { Significance }^{\mathrm{a}} \\
\text { of }\end{array}$ & & & & & & & \\
\hline & $\begin{array}{l}\text { Soli water } \\
\text { (SW) }\end{array}$ & $\mathrm{ns}$ & ns & ns & ns & ns & ns & ns \\
\hline & Inoculation (I) & ns & $* *$ & $* *$ & $* *$ & $* *$ & $* *$ & $* *$ \\
\hline & $\mathrm{SW} \times \mathrm{I}$ & ns & $* *$ & $* *$ & $*$ & $*$ & $* *$ & $* *$ \\
\hline \multirow[t]{8}{*}{$\mathrm{D} / \mathrm{nM}$} & $\mathrm{W} / \mathrm{nM}$ & $0.44 b^{b}$ & $0.04 \mathrm{a}$ & $1.10 \mathrm{~b}$ & $0.20 \mathrm{a}$ & $0.02 \#$ & $0.24 \mathrm{~b}$ & $0.06 \mathrm{a}$ \\
\hline & W/M & $0.59 \mathrm{~d}$ & $0.07 \mathrm{c}$ & $1.88 \mathrm{~d}$ & $0.61 \mathrm{c}$ & $0.06 \# \mathrm{~A}$ & $0.62 \mathrm{~d}$ & $0.35 \mathrm{c}$ \\
\hline & $\mathrm{D} / \mathrm{nM}$ & $0.18 \mathrm{a}$ & $0.03 \mathrm{a}$ & $0.90 \mathrm{a}$ & $0.16 \mathrm{a}$ & 0.01 & $0.06 \mathrm{a}$ & $0.04 \mathrm{a}$ \\
\hline & $\mathrm{D} / \mathrm{M}$ & $0.50 \mathrm{c}$ & $0.05 b$ & $1.39 \mathrm{c}$ & $0.43 b$ & $0.05 \mathrm{~A}$ & $0.53 \mathrm{c}$ & $0.21 \mathrm{~b}$ \\
\hline & Significance of & & & & & & & \\
\hline & $\begin{array}{l}\text { Soil water } \\
\text { (SW) }\end{array}$ & $* *$ & $* *$ & $* *$ & $* *$ & $* *$ & $* *$ & $* *$ \\
\hline & Inoculation (I) & $* *$ & $* *$ & $* *$ & $* *$ & $* *$ & $* *$ & $* *$ \\
\hline & $\mathrm{SW} \times \mathrm{I}$ & $* *$ & $*$ & $* *$ & $*$ & ns & $*$ & $* *$ \\
\hline \multirow[t]{8}{*}{$\mathrm{W} / \mathrm{M}$} & $\mathrm{W} / \mathrm{nM}$ & 0.50 & 0.06 & 1.75 & 0.47 & 0.05 & 0.59 & 0.26 \\
\hline & W/M & 0.58 & 0.06 & 1.77 & 0.45 & 0.05 & 0.58 & 0.24 \\
\hline & $\mathrm{D} / \mathrm{nM}$ & 0.57 & 0.07 & $1.84 \#$ & $0.58 \#$ & 0.05 & 0.61 & $0.32 \#$ \\
\hline & $\mathrm{D} / \mathrm{M}$ & 0.60 & 0.07 & 1.89 & 0.49 & 0.06 & 0.64 & $0.37 \#$ \\
\hline & Significance of & & & & & & & \\
\hline & $\begin{array}{l}\text { Soil water } \\
\text { (SW) }\end{array}$ & ns & $* *$ & $* *$ & $*$ & $*$ & ns & $* *$ \\
\hline & Inoculation (I) & $\mathrm{ns}$ & $*$ & ns & ns & ns & ns & ns \\
\hline & $\mathrm{SW} \times \mathrm{I}$ & ns & ns & ns & ns & ns & ns & ns \\
\hline \multirow[t]{8}{*}{$\mathrm{D} / \mathrm{M}$} & $\mathrm{W} / \mathrm{nM}$ & $0.69 \mathrm{~b}$ & $0.08 \mathrm{~b}$ & $1.94 \mathrm{~b}$ & $0.64 b$ & $0.06 \mathrm{~b}$ & $0.67 \mathrm{~b}$ & $0.41 \mathrm{~b}$ \\
\hline & W/M & $0.69 \mathrm{~b}$ & $0.08 \mathrm{~b}$ & $2.06 \mathrm{~b}$ & $0.67 \mathrm{~b}$ & $0.06 \mathrm{~b}$ & $0.72 b$ & $0.44 b c$ \\
\hline & $\mathrm{D} / \mathrm{nM}$ & $0.47 \mathrm{a}$ & $0.05 \mathrm{a}$ & $1.41 \mathrm{a}$ & $0.38 \mathrm{a}$ & $0.04 \mathrm{a}$ & $0.50 \mathrm{a}$ & $0.18 \mathrm{a}$ \\
\hline & $\mathrm{D} / \mathrm{M}$ & $0.72 b$ & $0.09 \mathrm{~b}$ & $2.10 \mathrm{~b}$ & $0.78 \mathrm{c}$ & $0.07 \mathrm{c}$ & $0.80 \mathrm{c}$ & $0.49 \mathrm{c}$ \\
\hline & Significance of & & & & & & & \\
\hline & $\begin{array}{l}\text { Soil water } \\
\quad(\mathrm{SW})\end{array}$ & $* *$ & $* *$ & $* *$ & ns & ns & ns & $* *$ \\
\hline & Inoculation (I) & $* *$ & $* *$ & $* *$ & $* *$ & $* *$ & $* *$ & $* *$ \\
\hline & $\mathrm{SW} \times \mathrm{I}$ & $* *$ & $* *$ & $* *$ & $* *$ & $* *$ & $* *$ & $* *$ \\
\hline
\end{tabular}

$n M$ “non-inoculated," $M$ “inoculated," $W$ “well-watered," $D$ “drought-stressed," ZmPIPs plasma membrane intrinsic proteins of maize

${ }^{\text {a }}$ ANOVA output: $* P<0.05 ; * * P<0.01 ;$ ns, not significant

${ }^{\mathrm{b}}$ Duncan's multiple-range test was performed across all treatments when interactions were significant, and $t$ test was performed to compare differences between treatments when there were no significant interactions. The same lowercase letter within a column indicates no significant difference at $P<0.05$ between treatments. \# and A indicate significant $(P<0.05)$ effects of the main factor "water" and "inoculation" in one compartment on the gene expression in the counterpart compartment, respectively
$\mathrm{D} / \mathrm{M}$ roots was observed in $\mathrm{D} / \mathrm{M}-\mathrm{D} / \mathrm{M}$ compared with $\mathrm{W} / \mathrm{nM}-\mathrm{D} / \mathrm{M}, \mathrm{W} / \mathrm{M}-\mathrm{D} / \mathrm{M}$, and $\mathrm{D} / \mathrm{nM}-\mathrm{D} / \mathrm{M}$, except for the non-significant difference in the expression of GintAQPF 2 between D/M-D/M and D/nM-D/M.
Unlike GintAQPF1 and GintAQPF2, Ri 14-3-3 exhibited significantly higher expression in the $\mathrm{D} / \mathrm{M}$ roots in $\mathrm{D} / \mathrm{nM}-\mathrm{D} / \mathrm{M}$ than in $\mathrm{W} / \mathrm{nM}-\mathrm{D} / \mathrm{M}$ and $\mathrm{W} / \mathrm{M}-\mathrm{D} / \mathrm{M}$ (Fig. 3; Table 6). 


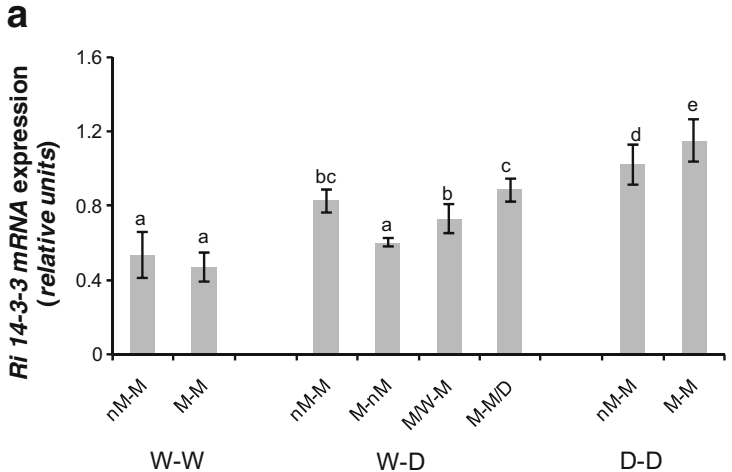

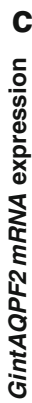

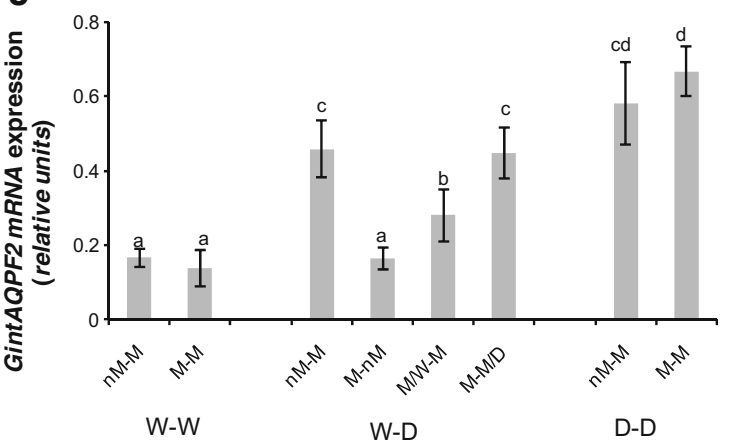

W-W

W-D

D-D
Fig. 3 Relative expression of Ri 14-3-3 (a), GintAQPF1 (b), and GintAQPF2 (c) from $R$. intraradices in mycorrhizal roots grown in a split-root system. Each compartment of the cultivation system was either inoculated $(M)$ or not $(n M)$ with $R$. intraradices and subjected to wellwatered $(W)$ condition or drought stress $(D)$. Only inoculated

\section{Discussion}

Although numerous studies have focused on the role of AMF in plant ABA accumulation and regulation of plant genes to cope with drought stress (Porcel et al. 2006a; Herrera-Medina et al. 2007; Aroca et al. 2008; RuizLozano et al. 2009), little is known about how AMF influence $\mathrm{ABA}$ distribution and signal transduction which largely influence plant drought tolerance in root systems subjected to heterogeneous treatments. Also there barely is any information about the potential

\section{b}

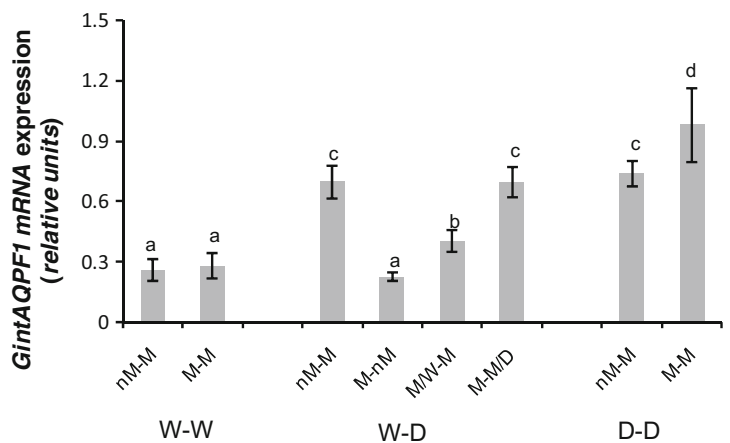

compartments were analyzed. The error bars represent SD $(n=4)$. Bars topped by the same lowercase letter do not differ significantly at $P<0.05$ by Duncan's multiple-range test. $M / W-M$ and $M-M / D$ indicate the inoculated compartments in W/M-D/M are under well-watered condition and under drought stress, respectively

linkages of ABA signaling pathways to the crosstalk between the symbiotic partners under drought stress. Based on a split-root experimental design, we unraveled physiological and molecular bases for enhancement of plant drought tolerance by AMF. The data presented here offer, to our knowledge, a first glimpse into the potential role of $\mathrm{ABA}$ in regulating the synergistic responses of AM symbionts to drought stress. In particular, we show that coordination of IPS and 14-3GF expression potentially plays a fundamental role in the crosstalk between maize and $R$. intraradices.
Table 6 Results of two-way ANOVA showing the statistical significance of the effects of mycorrhizal inoculation and soil water regime in one compartment (compartment 1) on relative expression of Ri14-3-3, GintAQPF1, and GintAQPF2 from $R$. intraradices in the counterpart inoculated compartment (compartment 2)

\begin{tabular}{|c|c|c|c|c|}
\hline $\begin{array}{l}\text { Compartment } 1 \\
\text { Treatment } \\
\text { clusters }\end{array}$ & $\begin{array}{l}\text { Compartment } 2 \\
\text { Factors }\end{array}$ & $\begin{array}{l}\text { Ri 14-3-3 } \\
\text { expression }\end{array}$ & $\begin{array}{l}\text { GintAQPF1 } \\
\text { expression }\end{array}$ & $\begin{array}{l}\text { GintAQPF2 } \\
\text { expression }\end{array}$ \\
\hline \multirow[t]{3}{*}{$\mathrm{W} / \mathrm{M}$} & $\begin{array}{l}\text { Soil water } \\
\text { (SW) }\end{array}$ & $*$ & ns & $*$ \\
\hline & Inoculation (I) & ns & $*$ & ns \\
\hline & $\mathrm{SW} \times \mathrm{I}$ & ns & $*$ & $*$ \\
\hline \multirow[t]{3}{*}{$\mathrm{D} / \mathrm{M}$} & $\begin{array}{l}\text { Soil water } \\
\text { (SW) }\end{array}$ & $* *$ & $*$ & $* *$ \\
\hline & Inoculation (I) & ns & ns & ns \\
\hline & $\mathrm{SW} \times \mathrm{I}$ & ns & ns & ns \\
\hline
\end{tabular}

$M$ "inoculated," $W$ "well-watered," $D$ "drought-stressed"

$* P<0.05 ; * * P<0.01 ;$ ns, not significant (ANOVA output) 


\section{Role of ABA in AM plant drought tolerance}

In accordance with the results of García Garrido et al. (2010), in our homogeneous treatments, expression of $D X S$ and $A O$, which encoded the enzymes catalyzing the first and last step of ABA biosynthesis, respectively, was remarkably upregulated in AM plants under well-watered conditions (Supplementary Table 4), demonstrating that ABA favors AM formation. However, under drought stress, AM plants, considered to be more tolerant to drought (Augé 2001; RuizLozano 2003), accumulated less ABA, as described by Ji et al. (2011) (Supplementary Table 3). The suppression of $A O$ was one of the main reasons for lower ABA concentration in mycorrhizal plants (Supplementary Table 4).

The reduced production of ABA induced expression of regulatory genes (Table S4). Here, we investigated two special regulatory factors responding to drought stress based on the work of Jia et al. (2006): 14-3GF involved in ABA signal transduction (Roberts et al. 2002), and IPS containing ABRE core sequences and involved in stress responses (Stevenson-Paulik et al. 2005; Murphy et al. 2008). It has been reported that 14-3-3 proteins serve as adaptors between ABA signaling effector viviparous 1 (VP1) and ABRE-binding factors (ABFs), and the resulting protein complex (PC) interacts with ABRE motifs and cooperatively controls the expression of ABA-regulated genes (Himmelbach et al. 2003; Schoonheim et al. 2007; Yoshida et al. 2010). In this way, mycorrhizal association significantly up-regulated the expression of ABA-inducible genes such as PIPS and SOD under drought stress (Supplementary Tables 4 and 5). The enhancement of antioxidant defense and water uptake helped AM plants to maintain significantly higher dry weight and relative water content (Fig. 2; Tables 2 and 3). Our results suggest that mycorrhizal association could enhance plant drought tolerance by lowering root $\mathrm{ABA}$ concentration, which in turn induced the expression of PIPS and SOD probably due to coexpression of IPS and 14-3GF.

\section{Importance of the coexpression of IPS and 14-3GF for systemic regulation of plant drought tolerance by $R$. intraradices}

In the heterogeneous treatments, although each compartment was subjected to independent treatment, the two parts of the root system showed similar root ABA concentration (Table 3) probably because of ABA redistribution among tissues (Christmann et al. 2006). Consistent with the effects of mycorrhizal inoculation on ABA production in the homogeneous treatments, both nM-M and M-M significantly decreased ABA concentration under drought stress (Table 3). The physiological activity of ABA is related not only to its biosynthesis and transport but also to sensitivity of target structures (Christmann et al. 2006). In this study, the target structure was the above-mentioned PC that interacted with ABRE motifs in IPS, because the results obtained from the homogeneous treatments showed that cooperation of IPS and 14$3 \mathrm{GF}$ potentially steered a positive effect on AM plant drought tolerance. In order to reveal the mechanisms of AM-specific regulation of drought tolerance in the heterogeneous circumstances, we focused on the correlation between expression of $I P S$ and $14-3 G F$ as a significant regulator of ABA-mediated gene expression and AM-mediated systemic drought tolerance.

In the W/M-D/nM treatment, $R$. intraradices induced expression of IPS, 14-3GF, and PIPS in non-mycorrhizal roots through interconnected shoots, while drought did not trigger an obvious response (except for ZmPIP2;1 and ZmPIP2;6) in the inoculated compartment, when compared with corresponding homogeneous controls (Tables 4 and 5). However, the $\mathrm{D} / \mathrm{M}$ and $\mathrm{W} / \mathrm{nM}$ roots in $\mathrm{W} / \mathrm{nM}-\mathrm{D} / \mathrm{M}$ displayed a reciprocal profile characterized by induction and repression of almost all PIPs in the $\mathrm{W} / \mathrm{nM}$ and D/M roots, respectively (Table 5). In any case, in view of shoot-root and root-root complex antagonistic interactions (Dickson 1991; Dewar 1993; Atzmon et al. 1994), mycorrhizal colonization did not activate the systemic regulation in both treatments and we highlight that cooperation of IPS and 14-3GF potentially displayed an important role in the AM-mediated systemic response of host plants to drought stress. We found that co-induction of IPS and 14$3 G F$ only happened in the roots exposed to drought stress in both W/M-D/nM and W/nM-D/M (here, the same expression levels of the two genes in the D/M roots in W/nM-D/M as that in $\mathrm{D} / \mathrm{M}-\mathrm{D} / \mathrm{M}$, which were the highest among the treatments, also were regarded as "co-induction"). This asynchronous expression profiling of IPS and 14-3GF in the whole root system might modulate shoot-to-root and root-to-root signaling and distribution of $\mathrm{C}$, water, and possible $\mathrm{P}_{\mathrm{i}}$ among tissues. Actually, there should be differences in $P_{i}$ uptake between the inoculated and non-inoculated roots because AM associations were established depending on exchanges of carbohydrates and mineral nutrients, in particular $\mathrm{P}_{\mathrm{i}}$, between the plants and the fungus (Smith and Read 2008). Consistently, our results indicated that mycorrhizal inoculation promoted plant absorption of water and $\mathrm{P}_{\mathrm{i}}$ and resulted in a significant increase in root relative water content and root $\mathrm{P}_{\mathrm{i}}$ concentration (Table 3 and Supplementary Table 3). In return, plants potentially produced higher root dry weight (Table 3 and Supplementary Table 3) that supported fungus growth. However, other than the inoculated roots, neither the noninoculated roots nor the shoots exhibited an obviously increased uptake of water and $\mathrm{P}_{\mathrm{i}}$. There was an exception for the W/M-D/nM treatment in which $R$. intraradices acted systemically through improvement of shoot $P_{i}$ status (Fig. 2c). One possible explanation was that the distribution patterns of $\mathrm{C}$ and water were different from that of $\mathrm{P}_{\mathrm{i}}$, but we could not exclude the possibility that there was an interaction between them, considering that plants have evolved sophisticated 
regulatory mechanisms to maintain $\mathrm{P}_{\mathrm{i}}$ homeostasis particularly under heterogeneous stress conditions (Doerner 2008).

Convincing evidence was that when co-induction of IPS and 14-3GF happened in both compartments in W/M-D/M and convergent coexpression of the two genes happened in the $\mathrm{D} / \mathrm{nM}-\mathrm{D} / \mathrm{M}$ system (Table 4 ), a significant increase in shoot relative water content in $\mathrm{D} / \mathrm{nM}-\mathrm{D} / \mathrm{M}$, and shoot dry weight and shoot $\mathrm{P}_{\mathrm{i}}$ concentration in both treatments (Fig. 2) could be attributed to the systemic regulation of drought tolerance by mycorrhizal association. Taken together, our data suggest that synergistic action of IPS and 14-3GF presumably coordinated the distribution of photosynthate and water between shoots and roots and activated the systemic effects of $R$. intraradices on plant drought tolerance under heterogeneous drought stresses.

\section{Potential involvement of IPS and 14-3GF in regulation of the crosstalk between maize and $R$. intraradices under drought stress}

Our previous work provided evidence for AMF transport of water via GintAQPF1 and GintAQPF2 to host plants (Li et al. 2013). In the present study, we observed remarkably higher expression of GintAQPF1 and GintAQPF2 in inoculated compartments under drought stress (Fig. 3b, c), implying the important role of AMF in enhancing plant drought tolerance. However, we could not determine if the performance was a direct response of the fungus itself to drought stress or, alternatively, was a response to crosstalk between host plants and AMF. To tackle this point, we focused on AMF gene expression in both W/M-D/nM and W/M-D/M, in which root relative water content and expression of $S O D$ in both W/M were similar to that in W/M-W/M (Tables 3 and 4), indicating that AM roots did not suffer from drought stress under our experimental conditions. In contrast to the plant gene expression profile in W/M-W/M, almost all of the detected genes were not significantly regulated in the W/M roots in W/M-D/nM, while, intriguingly, only IPS, $14-3 G F$, and ZmPIP2;6 were up-regulated in the W/M roots in W/M-D/M (Tables 4 and 5). It should be noted that significant alterations in the expression of AMF genes Ri 14-3-3, GintAQPF1, and GintAQPF2 were only observed in the W/M roots in W/M-D/M (Fig. 3). This subsequently contributed to a significant increase in shoot dry weight in W/M-D/M in comparison to the uninoculated control (Fig. 2a). Based on these findings, we propose that co-induction of IPS and $14-3 G F$ is fundamentally important for activation of protective effects of $R$. intraradices on host plants against drought stress. The 14-3-3 protein from AMF could potentially regulate signaling pathways in both host plants and AMF and enhance drought tolerance of the AM symbiosis (Porcel et al. 2006b). Apart from that, emerging evidence from the present study suggests that the potential cooperation of IPS and 14-3GF possibly triggers AMF 14-3-3 protein-mediated signaling pathways and up-regulates the activity of GintAQPF1 and GintAQPF2, and conversely AMF 14-3-3 protein is likely to influence functions of plant proteins via regulation of both IPS and 14-3GF in plants. All in all, these data favor a model whereby crosstalk between AM symbiotic partners at least partially depends on coexpression of $I P S$ and $14-3 G F$.

In conclusion, we identify that mycorrhizal colonization can decrease root $\mathrm{ABA}$ concentration mainly by down-regulating $A O$ expression under drought stress. Consequently, $R$. intraradices improves plant water status by modulating ABA-mediated abiotic signaling pathway involving IPS and 14-3-3 proteins. Moreover, the study on the action mode of $R$. intraradices in enhancing plant drought tolerance under heterogeneous conditions reveals that when IPS and 14-3GF are co-expressed in the whole root system, the systemic regulation of plant drought tolerance by $R$. intraradices is activated. We propose that cooperation of IPS and 14-3-3 protein potentially is responsible for the crosstalk between maize and $R$. intraradices, which is crucial to AM-associated synergistic actions in improving plant drought tolerance.

Acknowledgments This study was financially supported by the National Natural Science Foundation of China (41371264, 41401281) and the Chinese Academy of Sciences (XDB15030102).

\section{References}

Aroca R, Vernieri P, Ruiz-Lozano JM (2008) Mycorrhizal and nonmycorrhizal Lactuca sativa plants exhibit contrasting responses to exogenous ABA during drought stress and recovery. J Exp Biol 59: 2029-2041

Atzmon N, Salomon E, Reuveni O, Riov J (1994) Lateral root formation in pine seedlings. II. The role of assimilates. Trees-Struct Funct 8:273-277

Augé RM (2001) Water relations, drought and vesicular-arbuscular mycorrhizal symbiosis. Mycorrhiza 11:3-42

Bárzana G, Aroca R, Ruiz-Lozano JM (2015) Localized and nonlocalized effects of arbuscular mycorrhizal symbiosis on accumulation of osmolytes and aquaporins and on antioxidant systems in maize plants subjected to total or partial root drying. Plant Cell Environ 38:1613-1627

Bray EA (1997) Plant responses to water deficit. Trends Plant Sci 2:48-54 Camp ROD, Przybyla D, Ochsenbein C, Laloi C, Kim C, Danon A, Wagner D, Hideg É, Göbel C, Feussner I, Nater M, Apel K (2003) Rapid induction of distinct stress responses after the release of singlet oxygen in Arabidopsis. Plant Cell 15:2320-2332

Christmann A, Moes D, Himmelbach A, Yang Y, Tang Y, Grill E (2006) Integration of abscisic acid signalling into plant responses. Plant Biol 8:314-325

De Smet I, Zhang H, Inzé D, Beeckman T (2006) A novel role for abscisic acid emerges from underground. Trends Plant Sci 11:434-439

Denby K, Gehring C (2005) Engineering drought and salinity tolerance in plants: lessons from genome-wide expression profiling in Arabidopsis. Trends Biotechnol 23:547-552 
Dewar RC (1993) A root-shoot partitioning model based on carbonnitrogen-water interactions and Munch phloem flow. Funct Ecol 7: 356-368

Dickson RE (1991) Assimilate distribution and storage. In: Raghavendra AS (ed) Physiology of trees. Wiley, New York, pp 51-85

Doerner P (2008) Phosphate starvation signaling: a threesome controls systemic Pi homeostasis. Curr Opin Plant Biol 11:536-540

Duncan DB (1955) Multiple range and multiple F-tests. Biometrics 11:1-42

Estrada-Luna AA, Davies FT (2003) Arbuscular mycorrhizal fungi influence water relations, gas exchange, abscisic acid and growth of micropropagated chile ancho pepper (Capsicum annuum) plantlets during acclimatization and post-acclimatization. J Plant Physiol 160: 1073-1083

Fujii H, Zhu JK (2012) Osmotic stress signaling via protein kinases. Cell Mol Life Sci 69:3165-3173

García Garrido JM, León Morcillo RJ, Martín Rodríguez JA, Ocampo Bote JA (2010) Variations in the mycorrhization characteristics in roots of wild-type and ABA-deficient tomato are accompanied by specific transcriptomic alterations. MPMI 23:651-664

Gónzalez-Guerrero M, Azcón-Aguilar C, Mooney M, Valderas A, MacDiarmid CW, Eide DJ, Ferrol N (2005) Characterization of a Glomus intraradices gene encoding a putative $\mathrm{Zn}$ transporter of the cation diffusion facilitator family. Fungal Genet Biol 42:130-140

Hauser F, Waadt R, Schroeder JI (2011) Evolution of abscisic acid synthesis and signaling mechanisms. Curr Biol 21:346-355

Herrera-Medina MJ, Steinkellner S, Vierheilig H, Ocampo Bote JA, García Garrido JM (2007) Abscisic acid determines arbuscule development and functionality in tomato arbuscular mycorrhiza. New Phytol 175:554-564

Himmelbach A, Yang Y, Grill E (2003) Relay and control of abscisic acid signaling. Curr Opin Plant Biol 6:470-479

Jeschke WD, Hartung W (2000) Root-shoot interactions in mineral nutrition. Plant Soil 226:57-69

Ji XM, Dong BD, Shiran B, Talbot MJ, Edlington JE, Hughes T, White RG, Gubler F, Dolferus R (2011) Control of abscisic acid catabolism and abscisic acid homeostasis is important for reproductive stage stress tolerance in cereals. Plant Physiol 156:647-662

Jia JJ, Fu JJ, Zheng J, Zhou X, Huai JL, Wang JH, Wang M, Zhang Y, Chen XP, Zhang JP, Zhao JF, Su Z, Lv YP, Wang GY (2006) Annotation and expression profile analysis of 2073 full-length cDNAs from stress-induced maize (Zea mays L.) seedlings. Plant J 48:710-727

Joshi-Saha A, Valon C, Leung J (2011) A brand new START: abscisic acid perception and transduction in the guard cell. Sci Signal 4:re4

Khalvati MA, Hu Y, Mozafar A, Schnidhalter U (2005) Quantification of water uptake by arbuscular mycorrhizal hyphae and its significance for leaf growth, water relations, and gas exchange of barley subjected to drought stress. Plant Biol 7:706-712

Li T, Hu YJ, Hao ZP, Li H, Wang YS, Chen BD (2013) First cloning and characterization of two functional aquaporin genes from an arbuscular mycorrhizal fungus Glomus intraradices. New Phytol 197:617-630

Li T, Lin G, Zhang X, Chen YL, Zhang SB, Chen BD (2014) Relative importance of an arbuscular mycorrhizal fungus (Rhizophagus intraradices) and root hairs in plant drought tolerance. Mycorrhiza 24:595-602

Libault M, Brechenmacher L, Cheng JL, Xu D, Stacey G (2010) Root hair systems biology. Trends Plant Sci 15:641-650

Lin K, Limpens E, Zhang ZH, Ivanov S, Saunders DGO, Mu DS, Pang EL, Cao HF, Cha HH, Lin T, Zhou Q, Shang Y, Li Y, Sharma T, van
Velzen R, de Ruijter N, Aanen DK, Win J, Kamoun S, Bisseling T, Huang SW (2014) Single nucleus genome sequencing reveals high similarity among nuclei of an endomycorrhizal fungus. PLoS Genet 10:e1004078

Munns R, Sharp RE (1993) Involvement of abscisic acid in controlling plant growth in soils of low water potential. Aust J Plant Physiol 20: 425-437

Murphy AM, Otto B, Brearley CA, Carr JP, Hanke DE (2008) A role for inositol hexakisphosphate in the maintenance of basal resistance to plant pathogens. Plant J 56:638-652

Neumann E, Schmid B, R mheld V, George E (2009) Extraradical development and contribution to plant performance of an arbuscular mycorrhizal symbiosis exposed to complete or partial rootzone drying. Mycorrhiza 20:13-23

Osakabe Y, Yamaguchi-Shinozaki K, Shinozaki K, Tran LS (2013) Sensing the environment: key roles of membrane-localized kinases in plant perception and response to abiotic stress. J Exp Bot $64: 445-458$

Peuke AD, Jeschke WD, Hartung W (1994) The uptake and flow of C, N and ions between roots and shoots in Ricinus communis L. III. Long distance transport of abscisic acid depending on nitrogen nutrition and salt stress. J Exp Bot 45:741-747

Peuke AD, Jeschke WD, Hartung W (2002) Flows of elements, ions and abscisic acid in Ricinus communis and site of nitrate reduction under potassium limitation. J Exp Bot 53:241-250

Pfaffl MW (2001) A new mathematical model for relative quantification in realtime RT-PCR. Nucleic Acids Res 29:45

Porcel R, Azcon R, Ruiz-Lozano JM (2004) Evaluation of the role of genes encoding for $\Delta^{1}$-pyrroline-5-carboxylate synthetase (P5CS) during drought stress in arbuscular mycorrhizal Glycine max and Lactuca sativa plants. Physiol Mol Plant P 65:211-221

Porcel R, Aroca R, Azcon R, Ruiz-Lozano JM (2006a) PIP aquaporin gene expression in arbuscular mycorrhizal Glycine max and Lactuca sativa plants in relation to drought stress tolerance. Plant Mol Biol 60:389-404

Porcel R, Aroca R, Cano C, Bago A, Ruiz-Lozano JM (2006b) Identification of a gene from the arbuscular mycorrhizal fungus Glomus intraradices encoding for a 14-3-3 protein that is upregulated by drought stress during the AM symbiosis. Microb Ecol 52:575-582

Roberts MR, Salinas J, Collinge DB (2002) 14-3-3 proteins and the response to abiotic and biotic stress. Plant Mol Biol 50:1031-1039

Ruiz-Lozano JM (2003) Arbuscular mycorrhizal symbiosis and alleviation of osmotic stress. New perspectives for molecular studies. Mycorrhiza 13:309-317

Ruiz-Lozano JM, Azcon R (1997) Effect of calcium application on the tolerance of mycorrhizal lettuce plants to polyethylene glycolinduced water stress. Symbiosis 23:9-22

Ruiz-Lozano JM, del Mar Alguacil M, Barzana G, Vernieri P, Aroca R (2009) Exogenous ABA accentuates the differences in root hydraulic properties between mycorrhizal and non mycorrhizal maize plants through regulation of PIP aquaporins. Plant Mol Biol 70:565-579

Ruíz-Sánchez M, Armada E, Muňoz Y, de Salamone IEG, Aroca R, Ruíz-Lozano JM, Azcón R (2011) Azospirillum and arbuscular mycorrhizal colonization enhance rice growth and physiological traits under well-watered and drought conditions. J Plant Physiol 168:1031-1037

Schoonheim PJ, Sinnige MP, Casaretto JA, Veiga H, Bunney TD, Quatrano RS, de Boer AH (2007) 14-3-3 adaptor proteins are intermediates in ABA signal transduction during barley seed germination. Plant J 49:289-301

Seki M, Narusaka M, Ishida J, Nanjo T, Fujita M, Oono Y, Kamiya A, Nakajima M, Enju A, Sakurai T, Shinozaki K (2002) Monitoring the expression profiles of 7000 Arabidopsis genes under drought, cold 
and high-salinity stresses using a full-length cDNA microarray. Plant J 31:279-292

Shinozaki K, Yamaguchi-Shinozaki K (2007) Gene networks involved in drought stress response and tolerance. J Exp Bot 58:221-227

Smith S, Read D (2008) Mycorrhizal symbiosis, 3rd edn. Academic Press, New York

Stevenson-Paulik J, Bastidas RJ, Chiou ST, Frye RA, York JD (2005) Generation of phytate-free seeds in Arabidopsis through disruption of inositol polyphosphate kinases. Proc Natl Acad Sci U S A 102: 12612-12617

Yoshida T, Fujita Y, Sayama H, Kidokoro S, Maruyama K, Mizoi J, Shinozaki K, Yamaguchi-Shinozaki K (2010) AREB1, AREB2, and ABF3 are master transcription factors that cooperatively regulate ABRE-dependent ABA signaling involved in drought stress tolerance and require $\mathrm{ABA}$ for full activation. Plant J 61:672-685 